\title{
An Innovative Study of the Cultivation of Film and Television Talents in Higher Vocational Colleges from the Perspective of Production-Teaching Integration
}

\author{
Bo Zhang, Weiqing Sun \\ Shanghai Publishing and Printing College, Shanghai, China \\ Email: 309752339@qq.com
}

How to cite this paper: Zhang, B., \& Sun, W. Q. (2021). An Innovative Study of the Cultivation of Film and Television Talents in Higher Vocational Colleges from the Perspective of Production-Teaching Integration. Advances in Applied Sociology, 11, 523-529. https://doi.org/10.4236/aasoci.2021.1111046

Received: October 13, 2021

Accepted: November 12, 2021

Published: November 15, 2021

Copyright (อ 2021 by author(s) and Scientific Research Publishing Inc. This work is licensed under the Creative Commons Attribution International License (CC BY 4.0).

http://creativecommons.org/licenses/by/4.0/ (c) (i) Open Access

\begin{abstract}
The integration of production and teaching has always been an important direction for the development of vocational education in China. In order to realize the extension of industrial chain driven by the construction of specialties, the Department of Film and Television Arts of Shanghai Publishing and Printing College has always taken the reform of higher vocational film and media talents training under the perspective of production-teaching integration as the key grasp. Furthermore, the college actively explores new models, new paths and new ideas under the background of production-teaching integration in higher vocational colleges and universities and practices the training of highly skilled talents in the direction of film and media with several effective measures.
\end{abstract}

\section{Keywords}

The Integration of Production and Teaching, High-Skilled Talents, New Paths

\section{The Background of Innovative Cultivation of Film and Television Talents in Higher Vocational Colleges}

With the continuous and vigorous development of China's film and television industry, the resources in the film and television market have been changed from domestic allocation to coordinated domestic and international allocation, and the expansion of the film and television industry chain has been continuously optimized and upgraded (Liang \& Wang, 2019). During the "Thirteenth Five-Year 
Plan" period, Shanghai has launched a series of industrial policies such as "Opinions on Accelerating the Innovation and Development of Shanghai's Cultural and Creative Industries" and "Implementation Measures on Promoting the Development of Shanghai's Film and Television Industry" to help promote the "Shanghai Culture" brand and enhance the city's soft power. In the context of the new era, several imminent issues have emerged in the process of training talents in broadcasting and film in higher vocational institutions. These issues include how to address the rapid development of the emerging industry of film and television and the dislocation lag of talent training, deepen the multi-dimensional cooperation between reform teaching and industry, and optimize the clear positioning of vocational education talent training (Wang, 2019a). To solve those issues, the College has found clear targets and stood in a new position to continue to explore the cultivation of film and television talents: guided by the craftsmanship from an international perspective, a diversified faculty composed of teachers from the school and enterprises, master classes with international and domestic project systems, and first-class practical teaching bases are important guarantees (Dai, 2018).

The coordinated efforts by "college-government-enterprise-innovation" and other means have truly realized the innovation of cultivation concepts of the integration of political consciousness and craftsmanship, and the innovation of the education mechanism of "career-oriented inspection". In addition, the cultivation adheres to international standards, innovation in the training and positioning of skilled personnel in the industry, and innovation in the training path where competition results can be transformed to the market (Wang, 2019a). Therefore, the College concentrates on cultivating compound talents that meet the needs of international and domestic first-line positions.

\section{Key Measures for the Cultivation of Compound Talents under the Background of Production-Teaching}

\section{1) Curriculum Development of Cultivation of Compound Talents}

Talent cultivation is inseparable from the market, and the cultivation of film and television talents should also target the market. After years of practice and exploration, the Department of Film and Television Art of Shanghai Publishing and Printing College has gradually formed a close connection with the national policies and cultures, the film and television market, and the needs of enterprises (Wang, 2019b). It has organically integrated curriculum development and job standard construction. In particular, for professional positions, a multi-dimensional knowledge system that complies with industry requirements in terms of job setting, business literacy and practical skills has been built up, and those requirements are integrated into the construction of the curriculum system and the formulation of curriculum standards. Moreover, the curriculum development that satisfies the cultivation needs of "collecting-editing-broadcasting-creating" and "one specializing with multiple abilities" has been actively promoted ( $\mathrm{Gu}, 2020)$. 
Through the "School-Platform Alliance", "School-Enterprise Alliance", and "School-Innovation Alliance" and other cooperation forums held every year, the College has actively integrated and communicated with the government, enterprises, and the market. Regardless of teaching staff, the syllabus, the enterprise practices, the incubation of works, the discovery of innovative and entrepreneurial talents, etc., the College fully respects the needs of film and television companies and market positioning (Zhao, 2004). On the basis of understanding the knowledge, ability, and quality requirements for skilled talents of the film and television industry, and combined with the reality of the College itself, the College adheres to the employment-oriented approach, takes the urgently needed talents in the market as cultivation targets, and revises teaching plans and teaching contents so that they can meet the integrated course system of "collecting-editing-broadcasting-creating". Apart from that, the College has continuously updated the talent and skill points needed in the new business of the film and television industry, including the integration of media practices and webcasting, so as to ensure the whole process of learning and training of film and television talents, and ensure that the core technology that students learn from the College is the most urgently needed in film and television industry (Liu, 2010).

Under the background of "mass entrepreneurship and innovation", the Department of Film and Television Arts has always been actively exploring new ways and new methods for school-enterprise integration under the new situation, and constantly expanding the ideas of school-enterprise cooperation. It has set up news collection and editing class, advertising order class, and video archive class, with characteristic training as the focus to attract enterprises to schools and promote production-teaching integration (Xu, 2017). For example, the news collection and editing class provides a platform for the cultivation of outstanding professionals in the news media industry by inviting senior media professionals in Shanghai to regularly teach students professional skills on the basis of schoolplatform cooperation. The advertising order class is based on the professional characteristics, combined with the actual situation of enterprises, and trained talents from multiple dimensions such as recruitment needs, job settings, and professional matching, so as to accurately grasp the employment needs. The video archives class aims at "paying attention to professional skills training, emphasizing practical innovation ability, and focusing on the cultivation of professional quality of video archives major", and trained urgently needed talents in the video archives industry, so as to meet the needs of the relevant market (Xu, 2006).

2) Relying on the Platform of the Smart Media Industry School to Carry out Project-based Teaching

In accordance with the standards of first-class higher vocational colleges, the College takes the mission of cultivating high-quality and skilled talents in film and television industry for the needs of the smart media industry chain, and innovates educational concepts and methods. By relying on the platform of the Department of Smart Media Industry, the College carries out project-based teaching and international and domestic master class with projects. On the basis of 
several large studios established successively, such as the China-Europe Children's Picture Book Studio, New Media of Art Event Studio, Creative Stage Art Studio, Art "Intelligent Creation" Innovation Studio, Film and Television in New Media Studio, etc., the College further improves the construction of systems and mechanisms to guarantee project-based studios and deepens the simultaneous construction and organic connection of professional groups and studios to create a more favorable teaching environment for talent training.

3) Aiming at the Demand of the Talent Market in the Film and Television Industry, and Promoting Coordinated Efforts of "School, Government, Enterprise, and Innovation"

Higher vocational colleges must actively adapt to the fast development of industrial transformation and upgrading and the dramatic changes of cross-industry integration in the training and teaching activities of film and television talents. The College has built up a new education system with the ability to serve industry clusters, and accelerated the formation of a talent training mechanism that combines production, teaching and research. The radio, film and television program production major create a "school-platform alliance", which can give full play to the advantages of both sides, accurately grasp the employment needs of enterprises, and create a real working atmosphere, laying a good foundation for cultivating application-oriented talents with operational skills. Since 2017, the College has cooperated with the TV News Center of Shanghai Radio and Television Station, Shanghai Culture, Radio, Film and Television Group Co., Ltd., Jiading Radio and TV Station, Baoshan Radio and TV Station, Huangpu News Center, Changning News and Publicity Center, Yangpu News Center and other TV stations and news centers to establish the "school-platform alliance". The two parties have established a long-term, comprehensive and in-depth cooperative partnership based on the principles of "complementary advantages, cooperative innovation, common development, and mutual win-win cooperation" to build a broader platform for students' internship training, innovation and entrepreneurship, and truly realize the innovation of the education mechanism of "careeroriented inspection".

4) In Accordance with International Standards and First-Line Talents, Carrying out Innovation in the Training and Positioning of Skilled Talents

Under the trend of globalization, international cooperation has become the norm, and international radio, film and television program production talents have become a new market demand. Film and television majors are based on three important guarantees of international and domestic subject-based master studios, a diversified teaching team from schools and enterprises, the first-class practice teaching base in the industry, and actively improving the skilled talent training path according to international standards and the innovation needs of the industry. Firstly, the College has established a Sino-European art creation master studio with internationally renowned artists from the Aalto University of the Arts in Finland, the European Illustrators Association, etc., and actively cultivated film and television talents with an international perspective in the form of work- 
shops and practical creative shooting. The College has also formed in-depth cooperation with Shanghai Film Group. By hiring iconic leaders, outstanding experts and professors in the field of film and television, it builds up a master class of domestic film and television production, actively promotes AI and other technologies, assists in independent innovation, and carefully trains all-media talents to explore diversified services and to effectively solve the problems of shortage of talents and insufficient technological innovation in the field of "smart media". Secondly, the College integrates resources and actively sets up a dual-teacher and dual-ability faculty. It has established a dual-level and dual-ability faculty team consisting of subject leaders, full-time teachers, industry backbones and industry experts. It has introduced industry technical talents, business backbones and management talents through appointment or part-time methods to participate in teaching, invited industry experts to serve as guest professors to the College to give lectures, and to build team of teachers composed of school teachers and corporate mentors. A teacher training linkage mechanism combining schools and enterprises is established to send young backbone teachers to enterprises for further training and participate in social project $R \& D$ operations, and talents from various industries are hired to teach frontier development trends, production processes, key technologies and career trends. The College actively explores opportunities for inter-school exchanges, school-enterprise exchanges, joint creation, and scientific research cooperation, keeps up with industry trends and technological developments, and improves teachers' practical teaching level. The College focuses on building a stable application-oriented teaching team composed of school teachers, film and television industry professionals, and business management personnel, with young and middle-aged as the main body, and with "high academic level, rich industry experience, and reasonable age level" to ensure the sustainable training of applied film and television talents. Thirdly, this major has built a high-definition camera and packaging laboratory, film and television animation cluster rendering experimental training room, special-shaped virtual interactive projection experimental training room, digital special effects production laboratory, three-dimensional interactive media creation laboratory, reality studio training room, laboratory exhibition center of Department of Film and Television, film and television experimental teaching center, etc. A production practice base for film and television media has been built in 2017, and 5.49 million construction funds have been invested in continuous construction in 2018. As of the end of 2020, the base has 600 sets of equipment worth over 1000 yuan, with a total value of 20.557 million yuan.

In addition, the College also has a practical teaching base for Liu Shunzhun, the leading one in the industry. The area of digital film and television training base is more than 3000 square meters now, with digital graphic creative training center, film and television training center, 3D digital game training center, etc. The practical training center equipment currently includes multifunctional computer room, game design center, film and television shooting, post-production, lighting design, stage design, virtual studio, film and television shooting, lighting training, 
etc., and the center is also equipped with a variety of well-known brands such as SONY, Alai, Sobe, Dayang, JANUT and INSTA360, which provides strong hardware support and venue guarantee for cultivating applied talents in the film and television industry.

\section{Conclusion}

Serving society is the starting point and fundamental goal of cultivating innovative talents in higher vocational colleges, and contributing to social stability and economic prosperity is the direction of innovative behavior. Shanghai Publishing and Printing College, through the curriculum development of compound talent training, and relying on the platform of the smart media industry college to carry out project-based teaching and target the talent market demand of the film and television industry. The coordinated efforts of "school, government, enterprise, innovation", combined with international standards, industry-leading skills training and positioning innovation, etc., can help to establish a film and television media ecosystem, with social needs as the starting point, and production-teaching integrating as the ending point by actively absorbing beneficial nutrients from corporate culture.

On the one hand, to school, the collaborative education platform can jointly improve students' practical skills and comprehensive application ability. Besides, to school's teachers, they can also serve the enterprises through the collaborative education platform to enhance teachers' own technological innovation and service capabilities. Under the background of the production-teaching integration, the College can help the campus culture to have regional and corporate cultural elements through the construction of corporate culture and the inheritance of regional culture. This contributes to forming a seamless connection from the value chain of talent cultivation in higher education institutions to that of the socialized mass production of enterprises, making the education system of higher education institutions and the production system of external enterprises complementary and inseparable. In addition, if colleges introduce the value-oriented innovation culture worked out by enterprises in the fierce market competition into the cultural ecology of higher vocational institutions, the ability of higher vocational institutions to survive and develop in adversity in the innovation culture will be enhanced, and the transformation of innovation achievements of higher vocational institutions into real productivity will be accelerated.

\section{Fund Program}

This research is co-funded by the project of "2021 Shanghai Vocational Education Group of Press and Publishing" and the key project of "2021 Planning Research Project of Shanghai Higher Education Association” (Project No.: Z2-18).

\section{Conflicts of Interest}

The authors declare no conflicts of interest regarding the publication of this paper. 


\section{References}

Dai, Y. (2018). "1+X"-A New Framework of the Modern Vocational Education and Training System. Vocational Education for Mechanical Industry, 13, 22.

Gu, Y. Y. (2020). Statistical Analysis of Award-Winning Data of Teaching Ability Competition of National Vocational Colleges Skill Competition in 2019. Vocational and Technical Education, 8, 4.

Liang, K. D., \& Wang, Y. N. (2019). An Analysis of the Path of Vocational Education Talent Cultivation and Evaluation Reform Based on "Three Teaching Reforms". Chinese Vocational and Technical Education, 16, 7.

Liu, X. (2010). Teaching Evaluation of Secondary Vocational Education under the Perspective of Knowledge View. Vocational Education Research, 8, 9.

Wang, X. Q. (2019a). Briefly Description of the Theory and Operation of Instructional Design. Education Science Forum, 8, 12.

Wang, Y. N. (2019b). An Important Engine for the Improvement of Teachers' Teaching Ability in Vocational Schools in the New Era-A Review on 2019 Yearly Teaching Ability Competition of National Vocational College Skills Competition. Chinese Vocational and Technical Education, 6, 14.

Xu, G. Q. (2006). Vocational Knowledge Theory and the Content Design of Vocational Education Course. Vocational Education Communication, 22, 9.

$\mathrm{Xu}$, G. Q. (2017). Review and Prospect of China's Vocational Education in 40 Years of Reform and Opening up. Contemporary Vocational Education, 4, 16.

Zhao, Z. Q. (2004). On Comprehensive Curriculum Development of Vocational Education. Vocational \& Technical Education Forum, 13, 21. 